\title{
Foreword
}

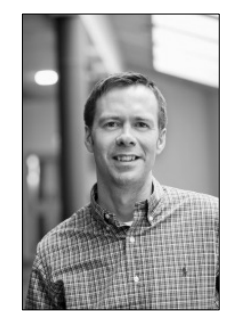

Associate professor

Axel Hilling

Lund University,

School of Economic and Management

Dear Reader,

The last few decades of globalization have involved a continuous growth in the number of multinational enterprises, dramatically changing the settings for tax law makers. New challenges have proven to be of such serious nature that the European Commission and the OECD have recently taken action in order to facilitate the making of national tax systems that stands strong in a truly international environment. Thus, the subject of the Nordic Tax Research Council's (NTRC) 2014 annual congress - Corporate Tax and the International Challenge - provides a good description of the main concern of the tax research community today. The congress took place at a beautifully located hotel by Hurdalssjøen, one hour south of the Norwegian capital, on May 22-23 this year. The reports presented on this congress are the main contents of this issue of the Nordic Tax Journal. The issue also contains scientific articles, one book review, and tax news reports from the five Nordic countries.

Before a short synopsis of the contents of this issue, I am pleased to inform you that the Nordic Tax Journal has applied to be enrolled on the three official academic ranking lists in the Nordic countries: the Norwegian, the Finnish, and the Danish lists. We expect feedback on our applications by late fall, and hope that this feedback will allow us to offer our authors the opportunity to publish their articles in a highly ranked journal. We are also working on a solution to provide our authors with the possibility of professional language editing for articles that we send for peer review. Finally, I am pleased to tell you that our publishing house, Djøf Publishing, is working on the introduction 
of a new web platform for its online journals, of which the Nordic Tax Journal is one. The new web solution will be fully compatible with all kinds of electronic devices, which, unfortunately, is not the current situation. It will also give us the opportunity to publish articles as they are accepted, instead of collecting all articles in the semi-annual issues, as we do today. I am convinced that the new web solution, which will be launched within a year, will make the Nordic Tax Journal an even more attractive journal.

Because the content of this issue is primarily based on the reports presented on NTRC's annual congress, our regular division into four sections is supplemented with the additional section: Reports. Thus, following is a short synopsis of our five sections: Peer-Reviewed Articles, Articles, Reports, Book Reviews, and Tax News.

\section{Peer-Reviewed Articles}

Internationalization and the ever-changing financial markets are two of the challenges that make today's tax law makers develop new models for collecting revenue. In the past, other challenges, like two world wars, have triggered the development of today's tax systems. Mikael Stenkula's article "Swedish Taxation in a 150-year Perspective" provides knowledge about the way Swedish tax law makers have met the major challenges that arose between 1862 and 2010. The study comprises various types of taxes, and provides valuable knowledge-based perspectives on future challenges and the tax law development that they may give rise to. Such a perspective cannot be undervalued in times like this, when several of the Nordic countries, along with other countries, has initiated processes for major changes in their national tax systems.

\section{Articles}

What may be a ground-breaking development in Swedish tax law - a unique model to tax corporate profit - was presented by the Swedish Government Committee on Corporate Taxation in June of this year. The model, which can be described as a modified CBIT, is based on the taxation of corporations' EBIT, but designed to offer better protection for the national tax base compared to other EBIT models - in Germany or Denmark, for example. Sven-Olof Lodin, appointed expert to the Committee, presents the new model and its potential strengths and weaknesses in his article "An overview of the Proposal of the Swedish Government Committee on Corporate Taxation". 


\section{Reports}

The subject for the NTRC's 2014 congress is presented in a general report by distinguished scholars representing the host country of the congress. Serving as the basis for the general report are economic and legal reports from the five Nordic countries, presented by scholars and experts in the relevant area. Before being published in the Nordic Tax Journal, reports have been discussed during the congress and revised on the basis of comments received there.

In the general report, "Corporate Income Tax and the International Challenge" Benn Folkvord and Michael Riis Jacobsen provide a general overview of the international challenge: over time, in a global perspective, and in a true Nordic perspective; various types of regulations to meet the international challenge are presented and commented upon. This presentation illustrates similarities and differences in the way the Nordic countries design their strategies to protect their corporate tax base and attract foreign investments. Among the regulations that are presented and commented upon are various GAARs, and such SAARs as CFC regulations and rules for limitations on the deductibility of financing expenses. The general report concludes by noting and thoroughly discussing two core challenges in the international tax environment: statutory tax rates and unequal treatment of debt and equity.

The Danish national reporters contribute to this issue with two reports - one economic and one legal. The economic report, written by Anna Holst Birket-Smith and Anders Fuglsig Larsen, describes developments in the Danish corporate income tax base and, thereby, developments in the corporate income tax rate, from 1990 until present. The report explains potential reasons for broadening the tax base and lowering the tax rate, and concludes by placing the Danish development in relation to future challenges in the international tax environment. In the legal report, Peter Koerver Schmidt provides a general view of the Danish corporate income taxation and the SAARs it comprises, including issues related to the extensive Danish tax treaty network. In a presentation of the avoidance rules, it is interesting to learn about the three sets of rules - the thin capitalization test, the asset test, and the EBIT test - which govern whether a corporation's financial expenses are possible to set off. These tests have no equivalent in the other Nordic countries.

In Finland, the limitation rules regarding the possibility for setting off financial expenses allow deductions of $25 \%$ of EBITDA. In the Finnish report, Juha Lindgren presents these newly introduced rules in detail, together with additional Finnish SAARs, the GAAR, and rules concerning tax incentives for attracting investments and estab- 
lishing companies. The report concludes by presenting some of the challenges facing Finland: it's geographical location close to Estonia, for example - a country with a corporate income tax system highly favourable to foreign investors.

The Icelandic report, written by Fjóla Agnarsdóttir and Rakel Jensdóttir, provides an interesting perspective on the international challenge. Although Iceland, like all other Nordic countries, is usually described as an open economy, the aftermath of the financial crisis in 2008 has forced the Icelandic government to apply capital control on cross-border movement of capital. This move has effectively closed the economy and rendered the BEPS issues less problematic and has made it challenging for Iceland to attract investments. It is notable that Iceland's anti-avoidance regulations are a recent occurrence; until 2009 tax avoidance could be fought only by using a general antiavoidance principle in the Icelandic income tax act.

Martin Børresen, Marius Pilgaard, and Marie Bjørneby present the Norwegian report, in which they argue that the highest corporate tax rate in the Nordic countries may negatively influence the level of investments in Norway. This high tax rate, together with a favourable tax treatment of debt compared to equity, exposes Norway to international challenge. The report presents measures taken to preserve the corporate tax base - new earnings stripping rules, for example, based on $30 \%$ of EBITDA. The report concludes by summarizing the commission for the Norwegian Corporate Tax Committee, which must present propositions for meeting the international challenge in the fall of this year.

Like the Danish reporters, the two Swedish reporters present their findings separately. In the economic report, Christina Thomann uses Swedish data on firm-level and sector-level taxation to investigate how much tax different sectors are paying in relation to their EBIT. Differences in the calculated tax rate are strongly related to the sectors' use of debt capital, Thomann argues. As a result, by disallowing deduction of interest expenses and thus harmonizing the effective tax on EBIT for the various sectors, the corporate income tax rate could be reduced by approximately $6 \%$, without losing any revenue. Given that the Swedish Government Committee on Corporate Taxation suggests strict limitations in the deductions of interest expenses, together with a reduction of the corporate income tax rate of $5.5 \%$, it appears that Thomann's findings have already had a serious impact ...

The legal report, presented by David Kleist, provides an overview of the Swedish corporate income tax system and how it is designed to attract investment and fight international tax avoidance. In this context, it is interesting to read about the Swedish interest deduction limitation rules, which differ from corresponding rules in the other Nor- 
dic countries, as the Swedish rule targets only illegitimate interest expenses rather than treating all interest expenses alike, as is done in Finland and Norway. The report highlights certain difficulties in the legal classification of a corporate interest expense as legitimate or illegitimate. Vague terminology like "actually entitled to the income" and "essentially motivated on commercial grounds" causes much of the difficulty.

\section{Book Reviews}

To provide an orientation to research conducted in the Nordic countries and to inspire improvements in the quality of future research, the Nordic Tax Journal is recurrently publishing researcher's views on other researcher's publications:

Jane Bolander provides an informative and useful review of Peter Koerver Schmidt's dissertation "Dansk CFC-beskatning - $i$ et internationalt og komparativt perspektiv". In his book, Koerver Schmidt provides a comprehensive analysis of the Danish CFC regulation in relation to Swedish, Norwegian, British, and U.S. dittos. Specific issues related to EU law and double tax treaties are given much attention in the study. Bolander reviews the dissertation in a propitious spirit, and considers it to be a valuable and topical contribution to Nordic tax research,

\section{Tax News}

Finally, our section on tax news presents new legislation and case law from the Nordic countries. In this issue, we are proud to present news reports from all five Nordic countries. To begin, however, we present Anders Nørgaard Laursen's extensive analysis of the truly Nordic decision by the European Court of Justice (ECJ) case C-48/13, Nordea Bank Denmark. The decision deals with the Danish rules for reincorporation of losses from permanent establishments situated in European Union/European Economic Area (EU/EEA) member states other than Denmark.

Inge Langhave Jeppesen presents, as always, an extensive and informative report on recent developments in Danish tax law. Jeppesen reports, among other things, that Denmark is following the Nordic trend set by Sweden and Norway by appointing a committee to review the corporate income taxation. Kristiina Äimä and Suvi Lamminsivu present the Finnish tax news, of which the recently presented action plan against international tax avoidance is one of the most fas- 
cinating. From Fjóla Agnarsdóttir's report on Icelandic tax news, it appears that the introduction of transfer pricing rules is the most significant tax event in 2014. In Ingvild Brandal Gaasemyr's report on Norwegian tax news the reader will learn about the extensive state aid scheme Norway applies in its sparsely populated areas, and that the scheme has been approved by the EFTA Surveillance Authority. Finally, the Swedish tax news report, presented by Pernilla Rendahl and David Kleist, focuses on the newly presented proposal for a new Swedish corporate income tax system and reviews a number of relevant court decisions within the area of VAT.

Good reading,

Axel Hilling

Editor 